Original Article

\title{
TOTAL POLYPHENOLIC CONTENT AND ANTIOXIDANT ACTIVITY OF SILYBUM MARIANUM CULTURES GROWN ON DIFFERENT GROWTH REGULATORS
}

\author{
HATTEM MEKKY1,2* , SAMAH EL SOHAFY'1, RASHA ABU EL-KHAIR ${ }^{1}$, AMR EL HAWIET1 \\ 1Department of Pharmacognosy, Faculty of Pharmacy, University of Alexandria, Egypt, 20man Pharmacy Institute, Ministry of Health, \\ Sultanate of Oman \\ Email: mekky870@gmail.com
}

Received: 28 Nov 2016 Revised and Accepted: 14 Feb 2017

\section{ABSTRACT}

Objective: The present study was designed to study the effect of supplementing Silybum marianum cultures with different combinations and concentrations of growth regulators on the total phenolic content and the antioxidant activity of the produced cultures.

Methods: The total polyphenolic content of 23 extracts of calli was calculated as $\mu$ g of gallic acid/mg of dry weight extract (DWE) using FolinCiocalteu reagent. The antioxidant activity was calculated as trolox equivalent antioxidant capacity using 1,1-Diphenyl-2-picryl-hydrazyl (DPPH) assay for extracts containing more than $10 \mu \mathrm{g}$ gallic acid/mg DWE.

Results: Most of the combinations showed an increase in the total polyphenolic concentration compared to the wild plant. However, cultures grown on media supplemented with combinations of benzyl aminopurine (BAP) and gebberellic acid (Gb), adenine (Ad) and kinetin (Kin), BAP and indole acetic acid (IAA) possessed the highest total polyphenolic contents 20.5, 13.09 and $12.15 \mu \mathrm{g}$ gallic acid/mg DWE, respectively. However, only $(\mathrm{BAP}+\mathrm{Gb}),(\mathrm{BAP}+1-\mathrm{Naphthaleneacetic}$ acid $(\mathrm{NAA}), \mathrm{IAA}$, kin and $(\mathrm{BAP}+\mathrm{Ad})$ showed a significant increase in the antioxidant activity calculated as trolox equivalent with $2.65,1.56,1.56,1.35$ and 1.22 folds increase over the wild plant, respectively.

Conclusion: The results obtained clearly indicated that changing the growth regulator system of Silybum marianum cultures serves as an easy and reliable method for increasing the total phenolic content and the antioxidant activity of cultures.

Keywords: Silybum marianum, Growth regulators, Polyphenolic, Antioxidant, Trolox, DPPH, Folin-Ciocalteu

(C) 2017 The Authors. Published by Innovare Academic Sciences Pvt Ltd. This is an open access article under the CC BY license (http://creativecommons.org/licenses/by/4. 0/A DOI: http://dx.doi.org/10.22159/ijpps.2017v9i4.16372

\section{INTRODUCTION}

Liver is one of the largest organs in the human body that performs several critical functions to detoxify the body of harmful substances [1]. Worldwide, liver diseases are regarded a major health problem. Globally in 2010, liver cirrhosis mortalities increased to over 1 million [2,3]. Additionally, World Health Organization (WHO) fact sheets indicate that 130-150 million people globally have chronic hepatitis $\mathrm{C}$ infection, of which a significant number would develop liver cirrhosis or liver cancer and 500,000 yly mortality due to complications of late-stage liver diseases. In Egypt, the problem is even worse $[4,5]$. Approximately $20 \%$ of Egyptian blood donors are anti-hepatitis C virus (anti-HCV) positive [6, 7].

Other estimates that Egypt has the highest prevalence of HCV worldwide, ranging from $6 \%$ to more than $40 \%$ among regions and demographic groups [8]. In Egypt, almost one-fifth (18.1\%) of male mortalities 45-to 54-years old are due to liver cirrhosis [3]. In spite of the tremendous advances in modern medicine, no effective medicines are available to treat some liver problems. This fact puts a challenge for scientists to explore the hepatoprotective activity of plants based on traditional use or try to increase the activity of available drugs [9-11]. Silybum marianum is a wellknown active hepatoprotective agent [12-14]. Silymarin, obtained from $S$. marianum is a widely used plant-derived hepatoprotective agent [15-19].

The properties of being antioxidant, free radical scavenger and stabilizer of the cell membrane are considered the important mechanisms of silymarin hepatoprotective action [20-24]. Thus, the aim of this work was to study the effect of different growth regulators combinations and concentrations on $S$. marianum cultures in an attempt to increase the activity using the antioxidant activity and the total polyphenolic concentration as a measure of the hepatoprotective activity of the grown cultures.

\section{MATERIALS AND METHODS}

Plant material

S. marianum aerial parts and fruits were collected from Khuorsheed, Alexandria. The fruits were collected during late April 2014. The aerial parts were collected from the same area during January 2015 in the pre-flowering stage and identified by the faculty of Science, University of Alexandria. Voucher specimens of the plant materials were deposited in the faculty of Pharmacy, University of Alexandria, specimen numbers (S. mar.1.14 and S. mar.1.15).

\section{Chemicals and reagents}

Murashige and Skoog (MS; Caission Laboratory, USA); BAP, Gb, Ad Kin, IAA, NAA, 2,4-D, DPPH, chitosan, high molecular weight, trolox, folin-ciocalteu reagent and methyl jasmonate (Sigma Aldrich, USA); agar (Roko, Spain); phenylalanaine (Universal Fine Chemicals PVT. LTD., India); sodium hypochlorite (5.25\%, Clorox $囚)$; tween 20 (Serva, Germany); gallic acid (Mallinckrodt Chemical Inc., USA); sucrose, sodium nitroprusside and all other solvents (El Nasr Pharmaceutical Chemicals Company, Egypt).

\section{Instruments}

Microplate reader, SPECTRO star Nano (BMG LABTECH, Germany) was used to get the results of both the total polyhenolics and the antioxidant capacity.

\section{Cell culture preparation and extraction procedure}

Fruits were surface sterilised in $20 \%$ "clorox" bleach (30 min), washed three times in sterile purified water. Hypocots were initiated on semi-solid MS media for $14 \mathrm{~d}(\mathrm{~d})$. The hypocots were then scored on their abaxial sides with a sterile scalpel blade and cut into $1 \mathrm{~cm}^{2}$ pieces. Explants were cultured on $25 \mathrm{ml}$ aliquots of MS regeneration medium with $1.5 \mathrm{mg} / \mathrm{l} \mathrm{BAP}, 1.5 \mathrm{mg} / \mathrm{l} 2,4 \mathrm{D}, 30 \mathrm{~g} / \mathrm{l}$ sucrose, and semi-solidified with $0.8 \%(\mathrm{w} / \mathrm{v})$ agar, $\mathrm{pH} 5.6$, in $9 \mathrm{~cm}$ 
diameter petri-dishes. The explants were transferred onto fresh medium until callus was produced.

Cell suspensions were established by transferring 1-2 g fresh weight (f. wt.) of rapidly growing, friable undifferentiated callus and maintained in $100 \mathrm{ml}$ MS liquid medium with same growth regulators, but no agar was added, pH 5.6 in 100 ml Erlenmeyer flasks. Cultures were maintained on a rotary shaker at $100 \mathrm{rpm}$ and incubated under a $16 \mathrm{~h}$ photoperiod, with day and night temperatures of $23^{\circ} \mathrm{C} \pm 1^{\circ} \mathrm{C}$.

For each growth regulator combination, aliquots of $2.5 \mathrm{ml}$ packed cell volume (PCV) with $2.5 \mathrm{ml}$ spent medium of the mother-stock were transferred to six $100 \mathrm{ml}$ erlenmeyer flasks, each containing $45 \mathrm{ml}$ of fresh media supplemented with the different growth regulators combinations. The cultures were kept at $23 \pm 1^{\circ} \mathrm{C}$, with a $16 \mathrm{~h}$ photoperiod and maintained on a rotary shaker at $100 \mathrm{rpm}$. After $28 \mathrm{~d}$, cultures were harvested, extracted in $70 \%$ ethanol, dried and dissolved in dimethyl sulfoxide (DMSO) with a concentration of $1 \mathrm{mg} / \mathrm{ml}$. Similarly, the fresh leafy samples were extracted and treated. Each experiment was repeated at least twice. All statistical analyses were performed by one-way analysis of variance (ANOVA) test, (design 2 between subject factors, $\mathrm{p}<0.000001)$.

Estimation of total phenolic contents in calli tissues using folinciocalteu reagent (F-C)

The assay that utilizes F-C describes a microplate-adapted colorimetric total phenolics assay. The assay depends on electrons transfer in alkaline medium from phenolic compounds to phosphomolybdic/phosphotungstic acid complexes, which are determined at $765 \mathrm{~nm}$ spectroscopically. The total phenolic content was expressed as gallic acid equivalents in $\mathrm{mg} / \mathrm{g}$ of DWE.

Twenty $\mu$ l of each extract, gallic acid standard concentrations (200$6.25 \mu \mathrm{g} / \mathrm{ml}$ ) or DMSO (solvent blank) was placed in a 96 well plate to which $40 \mu \mathrm{l} 10 \% \mathrm{~F}-\mathrm{C}$ were added, the plate was gently shaken, then $160 \mu \mathrm{l} 700 \mathrm{mmol} \mathrm{Na} \mathrm{CO}_{3}$ were added into each well and the plate was incubated at room temperature for $2 \mathrm{~h}$. The color intensity was assayed using a microplate reader spectrophotometer adjusted at $765 \mathrm{~nm}$. Total phenolics were calculated as gallic acid equivalents using the regression equation between gallic acid standards and $\mathrm{A}_{765}$ [25]. Calibration curve of gallic acid ( $\mu$ g concentration vs absorbance at $765 \mathrm{~nm}$ ) is given in fig. 1 .

\section{Determination of the total antioxidant capacity-DPPH assay}

The antioxidant capacity of Silybum extracts was determined relying on the redox potential of DPPH. The DPPH molecule is a stable free radical with a delocalized spare electron showing an absorption band in methanol at $520 \mathrm{~nm}$ yielding a deep violet colour.

In the presence of an antioxidant, DPPH is reduced with the consequent loss of the violet colour. $1 \mathrm{mmol}$ DPPH solution $(0.394$ $\mathrm{mg} / \mathrm{ml}$ ) in methanol was prepared and then diluted 1:10 to obtain a $100 \mu \mathrm{M}$ solution (Abs515 $\mathrm{nm}=0.5-0.6) .100 \mu \mathrm{ml}$ of each extract, trolox standard concentrations $(25-0.78 \mu \mathrm{g} / \mathrm{ml}$ ) or DMSO (solvent blank) was placed in a 96 well plate to which $100 \mu \mathrm{ml}$ of $100 \mu \mathrm{M}$ $\mathrm{DPPH}$ solutions were mixed. Negative control was prepared with $100 \mu \mathrm{L}$ of methanol and $100 \mu \mathrm{l}$ of DPPH solution. All solutions were incubated in the dark at room temperature for $15 \mathrm{~min}$. Absorbance was read at $\lambda=515 \mathrm{~nm}$. Results were expressed as the percentage of reduction of the radical absorbance [26].

[Abs max (negative control)-Abs (sample+DPPH)] * 100/Abs max

Where Abs max (negative control) is the absorbance $100 \mu \mathrm{l}$ of methanol and $100 \mu \mathrm{l}$ of DPPH solution and Abs (sample+DPPH) is the absorbance of $1000 \mu \mathrm{l}$ of the sample and $100 \mu \mathrm{l}$ of $100 \mu \mathrm{M} \mathrm{DPPH}$ solutions at $515 \mathrm{~nm}$. Calibration curve of trolox antioxidant activity ( $\mu \mathrm{g}$ concentration vs \%inhibition) is given in fig. 2.

\section{RESULTS AND DISCUSSION}

Results for total phenolic contents in calli tissues and total antioxidant capacity are presented in table 1 .

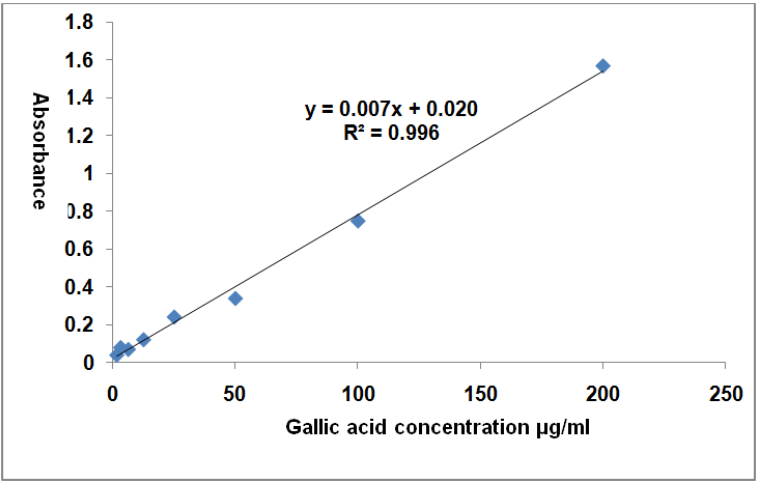

Fig. 1: Standard calibration curve of gallic acid ( $\mu \mathrm{g}$ concentration vs absorbance at $765 \mathrm{~nm}$ )

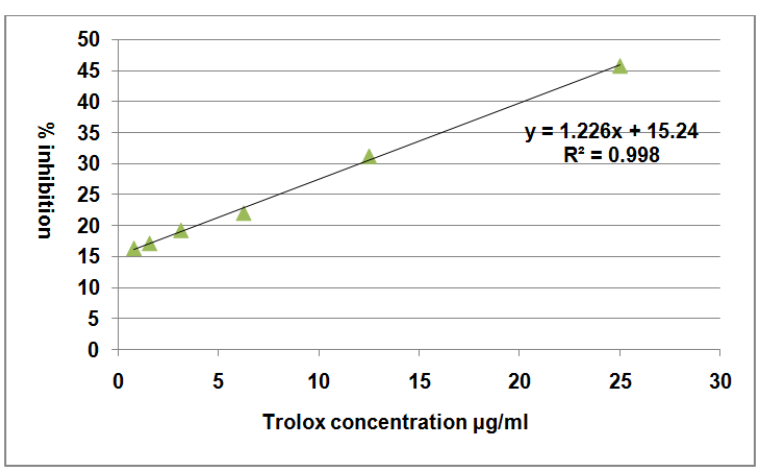

Fig. 2: Standard calibration curve of trolox antioxidant activity ( $\mu$ g concentration vs \% inhibition)

Silymarin, the purified fruit and seed extract of $S$. marianum (commonly known as milk thistle), has long been considered as the most powerful hepatoprotective agent. It was first thought to be a single compound with the structure of 7-chromanol-3-methyltaxifolin; recently it was found to be a mixture of several compounds namely silybin, isosilybin, silydianin and silychristin [22, 23]. Silymarin's hepatoprotective effects are accomplished via several mechanisms including antioxidation, free radical scavenging properties and stabilisation of cell membrane $[20,21,24,27]$, inhibition of lipid peroxidation [28, 29], protection of glutathione depletion [30]. Recently, studies have shown silymarin exhibits several anti-inflammatory effects [31, 32]. Silymarin has also promotes hepatic tissue regeneration through increasing hepatocyte protein synthesis [33]. Recent studies showed that silybin can also slow or even reverse fibrosis [34,35] and has immunomodulatory effects on diseased liver [36, 37].

Antioxidant activity is considered the most important and is strongly linked to the polyphenolic content of the plant $[38,39]$. In this study, supplementing the media with different growth regulators resulted in a general significant increase in the total phenolic content and consequently affected the antioxidant activity of $S$. marianum cell culture extract. Examining the results, it is clear that presence of IAA and/or BAP in the culture media induces a significant increase in phenolic synthesis pathway. Our results are in accordance with Taviera et al. (2009) and Sayd et al. (2010) that showed that media supplemented with increased BAP produced higher phenolic compound content [40,41]. Furthermore, Anastasia et al. (2010) showed that IAA significantly increases the production of phenolics in lentil plants [42]. Moreover, combining Gb and BAP resulted in the highest total phenolics production $(20.5 \mu \mathrm{g})$ and this is in concurrence with the results of Jeong et al. (2007) who concluded that, hairy roots of Panax ginseng requires the presence of gibberellic acid and cytokinins in order to have an increase in the total phenolic compounds in culture [43]. However, only cultures supplemented with $(\mathrm{BAP}+\mathrm{Gb}), 3 \mathrm{mg} / \mathrm{l} \mathrm{IAA},(\mathrm{BAP}+\mathrm{NAA}), 3 \mathrm{mg} / \mathrm{l} \mathrm{Kin}$ or $(\mathrm{BAP}+\mathrm{Ad})$ showed a significant increase in the antioxidant efficiency. 
Table 1: Mean $\mu$ g of gallic acid/mg DWE and mean trolox equivalent antioxidant capacity of samples of $S$. marianum cultures grown on different concentrations and combinations of growth regulators

\begin{tabular}{|c|c|c|c|}
\hline S. No. & Sample & Mean $\mu$ gs of gallic acid/mg DWE & $\begin{array}{l}\text { Mean } \mu g s \text { trolox equivalent antioxidant } \\
\text { capacity/mg DWE }\end{array}$ \\
\hline 1 & Fresh leaves (Khourshed) & $4.77 \pm 0.09$ & $5.42 \pm 0.24$ \\
\hline 2 & Ad $1.5 \mathrm{mg} / \mathrm{l}+\operatorname{Kin} 1.5 \mathrm{mg} / \mathrm{l}$ & $13.09 \pm 0.13(\mathrm{p}<0.0001)$ & $1.55 \pm 0.11(\mathrm{p}<0.0001)$ \\
\hline 3 & IAA $1.5 \mathrm{mg} / \mathrm{l}+\mathrm{Ad} 1.5 \mathrm{mg} / \mathrm{l}$ & $6.75 \pm 0.97(p<0.1116)$ & - \\
\hline 4 & BAP $1.5 \mathrm{mg} / \mathrm{l}+\mathrm{NAA} 1.5 \mathrm{mg} / \mathrm{l}$ & $10.01 \pm 0.2(\mathrm{p}<0.0001)$ & $8.48 \pm 0.09(p<0.0003)$ \\
\hline 5 & BAP $1.5 \mathrm{mg} / \mathrm{l}+\mathrm{IAA} 1.5 \mathrm{mg} / \mathrm{l}$ & $12.15 \pm 0.12(\mathrm{p}<0.0001)$ & $3.75 \pm 0.12(\mathrm{p}<0.0002)$ \\
\hline 6 & NAA $1.5 \mathrm{mg} / \mathrm{l}+\mathrm{IAA} 1.5 \mathrm{mg} / \mathrm{l}$ & $9.09 \pm 0.1(\mathrm{p}<0.0001)$ & - \\
\hline 7 & $\mathrm{NAA} 1.5 \mathrm{mg} / \mathrm{l}+2 \mathrm{Ph}$ ind $1.5 \mathrm{mg} / \mathrm{l}$ & $8.82 \pm 0.03(\mathrm{p}<0.0001)$ & - \\
\hline 8 & IAA $3 \mathrm{mg} / \mathrm{l}$ & $10.00 \pm 0.01(\mathrm{p}<0.0001)$ & $8.49 \pm 0.12(p<0.0003)$ \\
\hline 9 & Kin $1.5 \mathrm{mg} / \mathrm{l}+\mathrm{NAA} 1.5 \mathrm{mg} / \mathrm{l}$ & $7.22 \pm 0.05(\mathrm{p}<0.0001)$ & - \\
\hline 10 & Kin $1.5 \mathrm{mg} / \mathrm{l}+\mathrm{BAP} 1.5 \mathrm{mg} / \mathrm{l}$ & $9.27 \pm 0.15(\mathrm{p}<0.0001)$ & - \\
\hline 11 & $2,4 \mathrm{D} 1.5 \mathrm{mg} / \mathrm{l}+\mathrm{IAA} 1.5 \mathrm{mg} / \mathrm{l}$ & $10.66 \pm 0.16(p<0.0001)$ & $3.45 \pm 0.15(\mathrm{p}<0.0022)$ \\
\hline 12 & IAA $1.5 \mathrm{mg} / \mathrm{l}+2 \mathrm{ph}$ ind $1.5 \mathrm{mg} / \mathrm{l}$ & $12 \pm 0.27(\mathrm{p}<0.0001)$ & $6.65 \pm 0.73(\mathrm{p}<0.1809)$ \\
\hline 13 & Kin $1.5 \mathrm{mg} / \mathrm{l}+\mathrm{Gb} 1.5 \mathrm{mg} / \mathrm{l}$ & $9.75 \pm 0.06(\mathrm{p}<0.0001)$ & - \\
\hline 14 & $\mathrm{BAP} 1.5 \mathrm{mg} / \mathrm{l}+\mathrm{Gb} 1.5 \mathrm{mg} / \mathrm{l}$ & $20.5 \pm 0.3(\mathrm{p}<0.0001)$ & $14.35 \pm 1.32(\mathrm{p}<0.0026)$ \\
\hline 15 & BAP $1.5 \mathrm{mg} / \mathrm{l}+\mathrm{Ad} 1.5 \mathrm{mg} / \mathrm{l}$ & $11.22 \pm 0.29(\mathrm{p}<0.0001)$ & $6.63 \pm 0.15(\mathrm{p}<0.0124)$ \\
\hline 16 & IAA $1.5 \mathrm{mg} / \mathrm{l}+\mathrm{Gb} 1.5 \mathrm{mg} / \mathrm{l}$ & $9.36 \pm 0.12(\mathrm{p}<0.0001)$ & - \\
\hline 17 & $2 \mathrm{ph}$ Ind $1.5 \mathrm{mg} / \mathrm{l}+\mathrm{Kin} 1.5 \mathrm{mg} / \mathrm{l}$ & $8.46 \pm 0.03(\mathrm{p}<0.0001)$ & - \\
\hline 18 & Kin 3 mg/l & $10.19 \pm 0.19(\mathrm{p}<0.0001)$ & $7.31 \pm 0.18(\mathrm{p}<0.0319)$ \\
\hline 19 & $2 \mathrm{ph}$ ind $1.5 \mathrm{mg} / \mathrm{l}+\mathrm{Ad} 1.5 \mathrm{mg} / \mathrm{l}$ & $6.37 \pm 0.01(\mathrm{p}<0.0001)$ & - \\
\hline 20 & $2,4 \mathrm{D} 3 \mathrm{mg} / \mathrm{l}$ & $9.01 \pm 0.15(\mathrm{p}<0.0001)$ & - \\
\hline 21 & IAA $1.5 \mathrm{mg} / \mathrm{l}+\mathrm{Kin} 1.5 \mathrm{mg} / \mathrm{l}$ & $10.53 \pm 0.42(\mathrm{p}<0.0002)$ & $4.07 \pm 0.34(\mathrm{p}<0.0319)$ \\
\hline 22 & $2 \mathrm{ph}$ ind $1.5 \mathrm{mg} / \mathrm{l}+\mathrm{Gb} 1.5 \mathrm{mg} / \mathrm{l}$ & $9.15 \pm 0.14(\mathrm{p}<0.0001)$ & - \\
\hline 23 & BAP $3 \mathrm{mg} / \mathrm{l}$ & $8.49 \pm 0.14(\mathrm{p}<0.0001)$ & - \\
\hline 24 & BAP $1.5 \mathrm{mg} / \mathrm{l}+2 \mathrm{ph}$ ind $1.5 \mathrm{mg} / \mathrm{l}$ & $8.63 \pm 0.37(\mathrm{p}<0.0005)$ & - \\
\hline
\end{tabular}

Values represent the mean of three replicates. Values are given as mean $\pm \mathrm{SD}, \mathrm{Ad}=$ adenine; $\mathrm{BAP}=\mathrm{benzylaminopurine;} \mathrm{2,4D=2,4-}$ dichlorophenoxyacetic acid; $\mathrm{Gb}=$ gibberellic acid; $\mathrm{IAA}=$ indoleacetic acid; $\mathrm{NAA}=1$-naphthaleneacetic acid; $2 \mathrm{Ph}$ ind= 2-phenylindole.

\section{CONCLUSION}

The results obtained clearly indicated that changing the growth regulator system of $S$. marianum cultures serves as an easy and reliable method for increasing the total phenolic content and thus the antioxidant activity of cultures. Further studies are required may be with the addition of some elicitors or precursors.

\section{CONFLICT OF INTERESTS}

Declared none

\section{REFERENCES}

1. Ram VJ. Herbal preparations as a source of hepatoprotective agents. Drug News Perspect 2001;14:353-63.

2. Byass P. The global burden of liver disease: a challenge for methods and for public health. BMC Med 2014;12:159.

3. Mokdad AA, Lopez AD, Shahraz S, Lozano R, Mokdad AH, Stanaway J, et al. Liver cirrhosis mortality in 187 countries between 1980 and 2010:a systematic analysis. BMC Med 2014;12:145.

4. Awadalla HI, Ragab MH, Nassar NA, Osman M. Risk factors of hepatitis C infection among Egyptian blood donors. Cent Eur J Public Health 2011;19:217-21.

5. Darwish MA, Faris R, Darwish N, Shouman A, Gadallah M, ElSharkawy M, et al. Hepatitis C and cirrhotic liver disease in the Nile Delta of Egypt: a community-based study. Am J Trop Med Hyg 2001;64:147-53.

6. Waked IA, Saleh SM, Moustafa MS, Raouf AA, Thomas DL, Strickland GT. High prevalence of hepatitis C in Egyptian patients with the chronic liver disease. Gut 1995;37:105-7.

7. Strickland GT. Liver disease in Egypt: hepatitis C superseded Schistosomiasis as a result of iatrogenic and biological factors. Hepatol 2006;43:915-22.

8. Lehman EM, Wilson ML. Epidemic hepatitis $C$ virus infection in Egypt: estimates of past incidence and future morbidity and mortality. J Viral Hepat 2009;16:650-8.

9. Riley TR, Smith JP. Preventive care in chronic liver disease. J Gen Int Med 1999;14:699-704.

10. El Sohafy SM, Alqasoumi SI, Metwally AM, Omar AA, Amer MM, Abou-Shoer MI, et al. Evaluation of the hepatoprotective activity of some plants belonging to the tribe Cynareae growing in Egypt. J Med Plants Res 2013;7:324-8.

11. Witte I, Berlin J, Wray V, Schubert W, Kohl W, Hofle G, et al. Mono and diterpenes from cell culture of Thuja Occidenalis. Planta Med 1983;49:216-21.

12. Bahmani M, Shirzad H, Rafieian S, Rafieian-Kopaei M. Silybum marianum: Beyond hepatoprotection. J EvidenceBased Complementary Altern Med 2015;20:292-301.

13. Pradhan SC, Girish C. Hepatoprotective herbal drug, silymarin from experimental pharmacology to clinical medicine. Indian J Med Res 2006;124:491-504.

14. Morazzoni P, Bombardelli E. Silybum marianum (Carduus marianus). Fitoterapia 1995;66:3-42.

15. Vargas-Mendoza N, Madrigal-Santillán E, Morales-González A, Esquivel-Soto J, Esquivel-Chirino C. Hepatoprotective effect of silymarin. World J Hepatol 2014;6:144-9.

16. Polyak SJ, Ferenci P, Pawlotsky J. Hepatoprotective and antiviral functions of silymarin components in HCV infection. Hepatol 2013;57:1262-71.

17. Dixit N, Baboota S, Kohli K, Ahmad S, Ali J. Silymarin: a review of pharmacological aspects and bioavailability enhancement approaches. Indian J Pharmacol 2007;39:172-9.

18. Fraschini F, Demartini G, Esposti D. Pharmacology of silymarin Clin Drug Invest 2002;22:51-65.

19. Luper S. A review of plants used in the treatment of liver disease: part 1. Altern Med Rev 1998;3:410-21.

20. Ligeret H, Brault A, Vallerand D, Haddad Y, Haddad PS. Antioxidant and mitochondrial protective effects of silibinin in cold preservation-warm reperfusion liver injury. J Ethnopharmacol 2008;115:507-14.

21. Dvorak Z, Kosina P, Walterova D, Simanek V, Bachleda P, Ulrichova J. Primary cultures of human hepatocytes as a tool in cytotoxicity studies: cell protection against model toxins by flavonolignans obtained from Silybum marianum. Toxicol Lett 2003;137:201-12.

22. Kvasnicka F, Biba B, Sevcık R, Voldrich M, Kratka J. Analysis of the active components of silymarin. J Chromatogr 2003;990:239-45.

23. Lee DYW, Liu Y. Molecular structure and stereochemistry of silybin A, silybin B, isosilybin A and isosilybin B isolated from Silybum marianum (milk thistle). J Nat Prod 2003;66:1171-4. 
24. Muriel P, Mourelle M. Prevention by silymarin of membrane alterations in acute $\mathrm{CCl}_{4}$ liver damage. J Appl Toxicol 1990; 10:275-9.

25. Ainsworth EA, Gillespie KM. Estimation of total phenolic content and other oxidation substrates in plant tissues using Folin-Ciocalteu reagent. Nat Protoc 2007;2:875-7.

26. Dal Toso R, Melandri F. Echinacea angustifolia cell culture extract, added value for sport and fitness. Natura Foods 2011;10:19-25.

27. Miguez M, Anundi I, Sainz-Pardo LA, Lindros KO. Hepatoprotective mechanism of silymarin: No evidence for the involvement of cytochrome P450 2E1. Chem Biol Interact 1994;91:51-63.

28. Nencini C, Giorgi G, Micheli L. Protective effect of silymarin on oxidative stress in rat brain. Phytomed 2007;14:129-35.

29. Bosisio E, Benelli C, Pirola O. Effect of the flavanolignans of Silybum marianum L. on lipid peroxidation in rat liver microsomes and freshly isolated hepatocytes. Pharmacol Res 1992;25:147-54.

30. Campos R, Garido A, Guerra R, Valenzuela A. Silybin dihemisuccinate protects against glutathione depletion and lipid peroxidation induced by acetaminophen on rat liver. Planta Med 1989;55:417-9.

31. Polyak SJ, Morishima C, Shuhart MC, Wang CC, Liu Y, Lee DY. Inhibition of T-cell inflammatory cytokines, hepatocyte NFkappa B signaling, and HCV Infection by Standardized Silymarin. Gastroenterology 2007;132:1925-36.

32. De La Puerta R, Martinez E, Bravo L, Ahumada MC. Effect of silymarin on different acute inflammation models and on leukocyte migration. J Pharm Pharmacol 1996;48:968-70.

33. Sonnenbichler J, Zetl I. Biochemical effects of the flavanolignane silibinin on RNA, protein and DNA synthesis in rat livers. In: Cody V, Middleton E, Harbourne JB. Plant Flavonoids in Biology and Medicine: Biochemical, Pharmacological, and Structure-Activity Relationships. New York: Alan R. Liss, Inc; 1986. p. 319-31.

34. Tsai JH, Liu JY, Wu TT, Ho PC, Huang CY, Shyu JC, et al. Effects of silymarin on the resolution of liver fibrosis induced by carbon tetrachloride in rats. J Viral Hepat 2008;15:508-14.
35. Jia J, Bauer M, Cho J, Ruehl M, Milani S, Boigk G, et al. Antifibrotic effect of silymarin in rat secondary biliary fibrosis is mediated by downregulation of procollagen $\alpha 1(\mathrm{I})$ and TIMP1. J Hepatol 2001;35:392-8.

36. Gharagozloo M, Karimi M, Amirghofran Z. Immunomodulatory effects of silymarin in patients with $\beta$-thalassemia major. Int Immunopharmacol 2013;16:243-7.

37. Amirghofran Z, Azadbakht M, Karimi MH. Evaluation of the immunomodulatory effects of five herbal plants. J Ethnopharmacol 2000;72:167-72.

38. Fidranny I, Sukowati A, Sukrasno S. In vitro antioxidant activities of various leaves extracts from five varities of Rambutan (Nephelium lappaceum) and it's correlation with total flavonoid, phenolic, carotenoid content. Asian J Pharm Clin Res 2015;8:139-43.

39. Fidranny I, Puspitasari N, Singgih M. Antioxidant activities, total flavonoid, phenolic, a carotenoid of various shells extracts from four species of legumes. Asian J Pharm Clin Res 2014;7:42-6.

40. Taviera M, Pereira DM, Sousa C, Ferreres F, Andrade PB, Martins A, et al. In vitro cultures of Brassica oleraceae L. var costata DC: Potential plant Bioreactor forantioxidant phenolic compounds. J Agric Food Chem 2009;57:1247-52.

41. Sayd SS, Taie HAA, Taha LS. Micropropagation, antioxidant activity, total phenolics and flavonoids content of Gardenia jasminoides Ellis as affected by growth regulators. Int J Acad Res 2010;2:184-91.

42. Anastasia E, Giannakoula F, Jelena J, Maksimovic M, Maksimovic DZ. The effects of plant growth regulators on growth, yield and phenolic profile of lentil plants. J Food Comp Anal 2012;28:46-53.

43. Jeong G, Woo J, Park D. Effect of plant growth regulators on growth and biosynthesis of phenolic compounds in genetically transformed hairy roots of Panax ginseng C. A. Meyer. Biotechnol Bioprocess Eng 2007;12:86-91.

\section{How to cite this article}

- $\quad$ Hattem Mekky, Samah EL Sohafy, Rasha Abu El-Khair, Amr El Hawiet. Total polyphenolic content and antioxidant activity of Silybum marianum cultures grown on different growth regulators. Int J Pharm Pharm Sci 2017;9(4):44-47. 